\title{
Development of Policy Network of Tenayan Raya Industrial Area
}

\author{
Ahmad Harakan \\ Universitas Muhammadiyah Makasar \\ Makasar, Indonesia \\ Email: ahmad.harakan@unismuh.ac.id
}

\begin{abstract}
Pekanbaru City as a Trade City, and City of Industrial goods and services has not been supported by the functioning of Industrial area which became the center of goods and services turnover. Pekanbaru City Government from 2006 has made the policy of Industrial development area located in Tenayan Raya District with 3700 hectares area. In Weber's theory about industrial location that the location of the industry should be put in place with the least cost. Where the minimum transportation and labor costs tend to be identical to the maximum profitability, the selection of the tenayan raya subdistrict location is considered to be appropriate with regard to three criteria: physical criteria, accessibility criteria, infrastructure criteria, network availability, and environmental criteria.
\end{abstract}

Keyword: Policy, Development, Industrial Area

\section{INTRODUCTION}

The development and growth of Pekanbaru City is increasingly rapidly making Pekanbaru City as one of the largest Metropolitan City in Indonesia. Pekanbaru economic growth last five years on average above 10 percent this is reinforced by a survey conducted by the University of Indonesia to cities in Indonesia, to be an investment destination for entrepreneurs, Pekanbaru became the best investment destination number 1 in Indonesia.

Pekanbaru has no natural resources as other regionals in Riau Province, its potential is only a very strategic geographical location, vast administrative area, and large population with high growth rate. Therefore Pekanbaru City establishes superior sectors as Service City, Trade City and Industrial City such as tourism industry and processed industry, in accordance with the Vision of Pekanbaru City in 2021, namely "The Realization of Pekanbaru City as Trade and Service Center, Education and Melayu Culture Center Towards Prosperous Society Based on Faith And Taqwa ".

Seeing the opportunities and challenges that Pekanbaru Municipal Government has made a policy development of tenayan area as an industrial area. However, until 2017 the policy has not yet been realized. This paper illustrates the construction of the tenaya area in Pekanbaru City viewed from a perspective to the policy network and location theory.

\section{DISCUSSION}

\section{A. Public Policy}

Public policy according to Dye (1981) is whatever the government's choice to do or not to do. The concept is very broad because public policy includes something not done by the government in addition to what the government does when the government faces a public problem. For example, when the government knows the road is damaged and the government does not make a policy to improve it means the government has taken a policy. The definition of public policy from Thomas Dye stems the meaning that:

1) These public policies are made by government agencies, not private organizations.

2) Public policy concerns the choices that should be made or not performed by government agencies.[1]

Anderson defines public policy as a policy established by government agencies and private agencies. Although it is realized that public policy can be influenced by actors outside the government.

To understand the various definitions of public policy, it good to discuss some of the key concepts contained in public policy. [2] including:

1) Appropriate government action. Public policy is an action that is created and implemented by a government agency with legal, political and financial authority to do so.

2) A reaction to real-world needs and problems. Public policy seeks to respond to problems or concrete needs developed in the community.

3) A set of goal-oriented actions. Public policy is usually not a single decision, but consists of several choices of actions or strategies that are made to 
achieve certain goals for the sake of the crowd.

4) A decision to do or not to do something. Public policy is generally a collective action to solve social problems. However, public policy can also be formulated based on the belief that social problems will be solved by the existing policy framework and the kenrenanya does not require a specific action.

5) A justification made by one or several actors. Public policy contains a statement or justification of the steps or action plan that has been formulated, not an intent or promise that has not been formulated. Decisions that have been formulated in public policy can be made by a government agency, as well as by some representatives of government agencies.

The scope of public policy can be said to be very broad because it covers various sectors or areas of development such as education, agriculture, health, transportation, defense, and so forth. In addition, judging from the hierarchy, public policy can be national, regional, and local, such as Laws, Regency / Municipal Government regulations, and District / Mayoral Decisions.

Good policy has no meaning if it can not be implemented. If a policy has been established, then the process of formulating the policy step on the implementation stage. This phase involves a series of activities that include notifications to the public about the policy choices taken, the policy instruments used, the staff to implement the program, the services to be provided, the prepared budget, and the reports to be evaluated.

Implementation of a policy is an activity of administrative activities as an institution is intended as one of the process of activities undertaken by administrative units or bureaucratic units.

In general, we can say that the implementation function is to establish a relationship that allows public policy goals or objectives to be realized as "outcomes" of government activities. The implementation function therefore involves the creation of what in the public policy science (Public Science) is called the "Polocy delivery system" (the system of public policy delivery / forwarding) which usually consists of certain means or facilities specially designed / designed as well as directed towards achieving the desired goals and objectives.

\section{B. Concept of Industrial Location}

To establish a comprehensive industrial location (large scale) requires a combination of knowledge and discipline. Factors to be considered in determining location include the availability of raw materials, labor wages, security guarantees, supporting facilities, local market absorption, and accessibility from production sites to targeted marketing areas (especially marketing accessibility to foreign countries), political stability a country, and a regional policy (local regulation).

Alfred Weber, a German economist who taught at the University of Prague from 1904 to 1907 and then at the University of Heidelberg (Germany) from 1907 to 1933, had the theory relating to least cost location that states that industrial premises should be put in place of the most cost minimal. Places where the minimum transportation and labor costs tend to be identical to the maximum profit level.

According to Weber, there are three main factors affecting the location of industry, firstly, the factor of labor. Secondly, transportation cost factors are common regional factors, and the three local and special deglomeration / agglomeration factors.

Weber is based on several key assumptions, such as the location of raw materials in a given place (given), the situation and size of the place of consumption is certain too, so there is a perfect competition. There are several places where workers are not easy to move. In drafting the concept, Weber simplified the imagination of a homogeneous and flat landscape, and the exclusion of wage labor and market reach.

By using the three assumptions above, then the cost of transportation will depend on two things, namely the weight of goods and hauling distance. If the basis of determinants is not weight but volume, then that determines the cost of transportation is the volume of goods and haulage distance. In principle, what must be known is a unit that is a functional relationship with the cost and the distance that must be taken in transporting it (have the same tariff). Here it can be assumed implicitly that the unit price of transport is everywhere the same, so the difference in freight costs is only due to the difference in the weight of the object being transported and the distance traveled.

In addition, Weber also grouped the industry into two, which are:

1) The weight losing industry (industries whose products have a lighter weight than their raw materials, for example the paper industry.The cost of transporting raw materials to factories will be more expensive when compared to the cost of transporting finished products to the market. should be located near the source of the material (resource oriented).

2) An industry of weight gaining type, hence better industrial location is placed near the market.

Weber also explained about the existence of industrial agglomeration gel. Symptoms of agglomeration is the concentration of production in a particular location. This concentration of production can occur in one company or in various companies that work on various products. This phenomenon attracts the industry from the location of 
minimum freight costs, as it brings various forms of external savings called aglomeration economies. Of course this displacement will lead to an increase in freight costs, so in terms of this is no longer optimum. Therefore, the new industry will move if the savings brought by agglomeration economies outweigh the increase in transport costs brought by the move.

\section{Critical Review}

The number of available investment opportunities ranging from small to large scale, ranging from food to power plants and palm oil derivatives industry and other investment opportunities such as housing, both middle class housing and elite housing and more store houses (ruko), becomes a potential which should be utilized by Pekanbaru City Government for the development and welfare of the community.

In a network there are two important parts of network structure, namely actors (nodes) and relationships between actors (links). Actors are not always individuals, but can also be organizations. some of relationship direction and interaction between network actors form a pattern so that to know the structure of the network pattern what is formed must be based on the pattern of interaction that occurred. Similarly, this Investment is not only by local entrepreneurs, but also regional, national and international that form the network pattern.

One of the investments that are being planned from national and international is the investment of the Waste Fueled Power Plant (PLBBS). This PLBBS will be built at Final Disposal Site (Final Disposal Site) of Muara Fajar. Maximize network of companies, G20 Environmental Solutions Group (ESG). The company is cooperating with BUMD Riau Investment Corporation (RIC) and PD Pekanbaru in a joint venture of Public Private Partnership. Besides Pekanbaru City where the transit of finished goods and raw big companies in Riau Province such as RAPP, Indah Kiat, Sinar Mas, Ara Abadi and Chevron through Siak river as the busiest transformation path in Riau Province which traversed large ships as supported deep river depth.

Ironically, the potential of Pekanbaru City as a Trade City and Industrial City of goods and services has not been supported by the functioning of Industrial area which becomes the center of goods and services turnover. Pekanbaru City Government from 2006 has made the policy of Industrial development area located in Tenayan Raya District with 3700 hectares area. Of the 3700 hectares of land is planned to also be developed for industrial areas, business centers, food industry, small industry, apparel and leather, wood and wooden products, chemical industry and chemical goods, and Pekanbaru City
Government office complex scale of 1000 hectares. Planned development begins with Pekanbaru City Government office center which is planned to cover 300 hectares. For now Pekanbaru Government office area is only owned 117 hectares. Later in the area, will be built 6 buildings, one main building consists of six floors and added 5 SKPD office five-story high.

In line with the development of tenayan industrial area, as a form of efforts of equitable development, the government of Pekanbaru City also has plans to move the office center Pekanbaru City. In addition, the plan to move the office center Pekanbaru City is also aimed to meet the challenges of Pekanbaru City development 50 years into the future. The planned removal of the central office will have an impact on changes in urban space structures and reduced traffic flow especially towards the city center.

Problems that occur today, until 2015 the development of Industrial area Tenayan Raya has not realized and abandoned caused by several problems including:

1) The access roads of the industrial area from the port are very bad, this can be seen with roads that have not been asphalted and difficult to pass if the rainy season, while the vehicles that operate transport large items. This raises the rise of rodent ports transporting goods through city streets that are forbidden for large vehicles to pass.

2) An area of 3700 hectares of Tenayan Industrial Estate (KIT) in Tenayan Raya sub-district, Pekanbaru was constrained because it was included in the compensation map area issued by the Minister of Forestry (Menhut) in November 2014.

3) The emergence of the latest government regulation is the Regulation of the Minister of Agrarian Affairs and Spatial / Head of National Land Agency. 5 of 2015 on Location Permit [7] contains multi-commentary elements and burdensome bureaucracy. Substance in general explains for industrial areas that require land above the provisions can be made after the National Land Agency received approval from the Minister of Agrarian Affairs and Spatial / Head of BPN raises the burden of bureaucracy. Due to the regulation, the developer must request permission from the BPN of the Regency / City then to the Provincial BPN up to the Minister.

4) Compensation of unfinished community land coupled with problems of land dispute that is not completed between the Government of Pekanbaru with the landowner community in Tenayan industrial area (KIT).

5) In detail the legislators do not know what kind of development of the industrial estate. In the plenary view of the Responsibility Report (LKPj) of Pekanbaru City Head of 2014 budget year is merely to convey the views and not directly responded by the government. 


\section{CONCLUSION}

The development of tenayan industrial zone in Pekanbaru City is a very appropriate policy when viewed the needs of the region will be a center of small and large scale industrial goods and services activities. The existence of the tenayan industrial zone will support the potential utilization of Pekanbaru City as a Trade City and Industrial City so that it will affect the regional competitiveness, investment climate, and the denial of the original income for the welfare of society. Structuring the right industrial estate will also have an impact on the distribution of development so as not to be centered on the central area of Pekanbaru City which raises demographic demography problems, congestion, and high crime rate.

\section{REFERENCE}

[1] Subarsono, Ag. Analisi Kebijakan Publik, 2008. Pustaka Pelajar. Yogyakarta.

[2] Suharto, Edi, , 2008. Analisis Kebijakan Publik, Alfabeta, Bandung.

[3] Soehartono, Irawan, 2007. Kebijakan Sosial Sebagai Kebijakan Publik, Alfabeta, Bandung,

[4] Awang, Azam, 2010, Implementasi Pemberdayaan Pemerintah Desa, Pustaka Pelajar, Yogyakarta

[5] Wahab, Solihin Abdul Wahab, 2008. Pengantar Analisis kebijakan public. UMM Press. Malang

[6] Artika, Tiara. 2010. "Aplikasi Teori Weber dalam Menentukan Lokasi",dalamhttp://kasihdalamkata.blogspot.com/2009/07/aplikasiteori-weber dalam-menentukan.html

[7] Peraturan Menteri Agraria dan Tata Ruang/ Kepala Badan Pertanahan Nasional No. 5 tahun 2015 tentang Izin Lokas 